\section{Ultralydsymposium 2013 i Sandefjord}

\author{
Fra 17. til 19. april 2013 avholdt NFUD sitt \\ 37. årlige symposium i Sandefjord.
}

137 registrerte deltagere gjenspeilte attraktiviteten av symposiet. Lene Terslev, Ioan Sporea, Ann Tabor og Ann Thurig som internasjonale, inviterte forelesere sikret programmets høye nivå sammen med nasjonale foredragsholdere, blant annet Hans Torp, Kjell Å. Salvesen, Knut Brabant, Harm-Gerd Blaas, Hilde Berner Hammer og Arne Heilo.

Åpningssesjonen hadde fokus på Dopplerultralyd i de forskjellige fagområder med mulighet for praktiske øvelser under veiledning direkte etterpå. Opplegget ble svært vellykket grunnet fengende foredrag, og engasjerte deltagere ved ultralydmaskinene til sent på kvelden.

Det lokale arrangementskomitéen med Beatrice Rüger i spissen sørget for et velegnet møtested og ikke minst underholdende A capella innslag under festmiddagen. Claudia Heien og Svein-Erik Måsøy fikk en varm avskjed etter mangeårig innsats $\mathrm{i}$ styret. Takk for maten tale med Nils Petter Oveland hjalp å fordøye festmiddagen, og mulighet for musikalsk beinstrekk avsluttet kvelden.

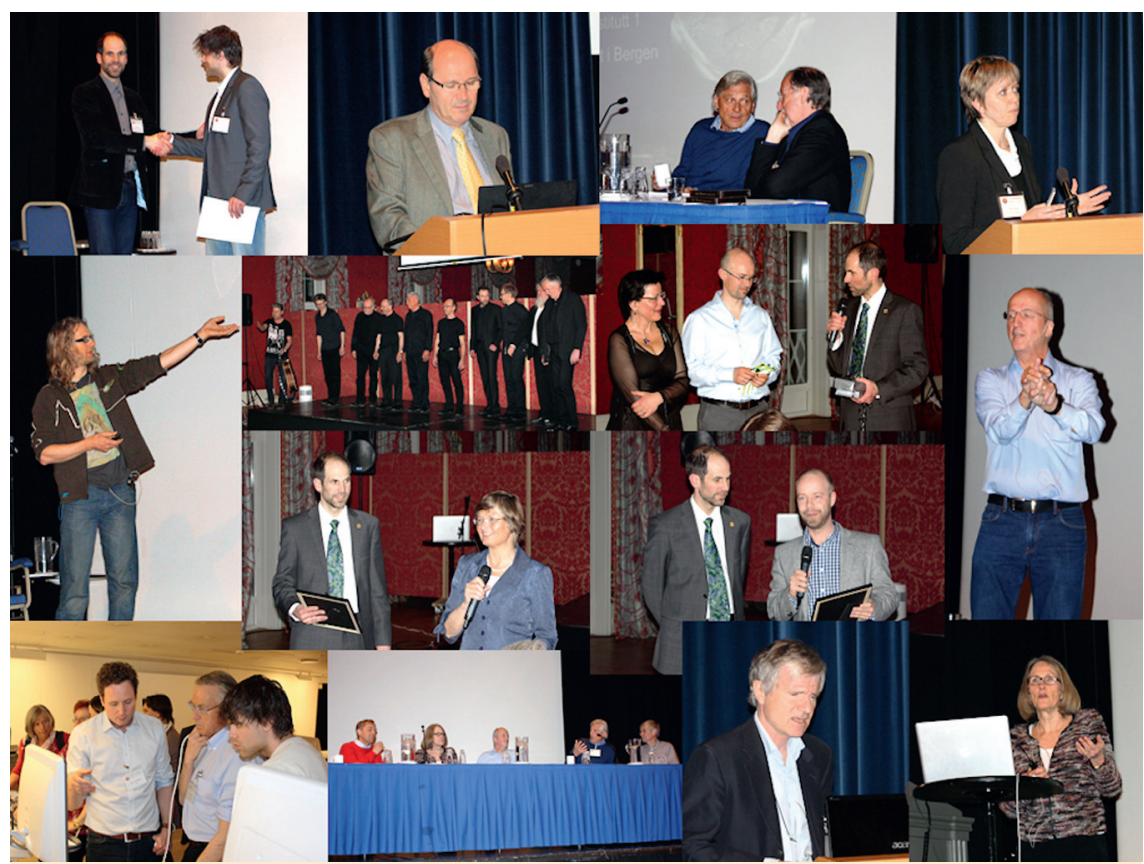

Inntrykk fra Ultralydsymposium 2013 i Sandefjord 